\title{
Social Forces and the International Political Economy after the 2008 Financial Crisis: The Case of Business Summit 20 (B20)
}

\author{
Leonardo Ramos* \\ https://orcid.org/0000-0001-8245-6498 \\ *Pontifícia Universidade de Minas Gerais, Belo Horizonte, Minas Gerais, Brazil \\ Pedro Henrique Schneider Parreiras** \\ https://orcid.org/0000-0003-4048-0021 \\ ** Federal University of Minas Gerais, Belo Horizonte, Minas Gerais, Brazil
}

The 2008 financial crisis stands out for being a crisis that occurred not in developing countries, but in the core capitalist countries, thus assuming greater proportions and with broader ramifications. In this context, the G20 gained new impetus, and, as a result, several studies have sought to understand not only the crisis but the role of the reformed G20 in the process of resolving it. Despite the relevance of this literature, little attention has been paid to the G20 outreach process, in particular to the growing dialogue established between the G20 and B20 (Business Summit 20 ), a group that represents the business sector in these exchanges. This article seeks to contribute to a better understanding of the engagement of business elites with the actions taken by the G20 to deal with the 2008 financial crisis - that is, the role of social forces in the (re)construction of contemporary international political economy. It seeks, in a concise and exploratory way, to sketch the relationship between the B20 and G20 in the period between 2010 and 2017, in order to better understand processes associated with the transnationalization of the capitalist class. It starts from the hypothesis that during this period it is possible to identify the constitution of a 'B20 Nucleus', constituted by the business sectors present at most B20 summits, and to a large extent based in the countries of the North Atlantic. In this sense, the B20 acts as a point of integration for the global corporate elite.

Keywords: B20; G20; hegemony; transnational capitalist class; crisis

http://dx.doi.org/10.1590/1981-3821201900020002

For data replication, see: https://doi.org/10.7910/DVN/WSNGJM

This publication is registered under a CC-BY Licence. 
ince the early 1990s it has been possible to trace the development of a

crisis of global capitalism, a crisis that has four specific and interrelated dimensions: 01. a crisis of social polarization; 02. a structural crisis of overaccumulation; 03. a crisis of legitimacy and authority; and 04. a sustainability crisis (HARVEY, 2005; RAMOS, 2013; STREECK, 2016; ROBINSON, 2004). These dimensions can be understood as structural factors underlying the crises that began in Mexico (1994), intensified in East Asia (1997-1998) and spread throughout the world during this period, with the last and most recent episode being the crisis of 2008.

What stands out about this latest crisis is that unlike previous ones it began in the core rather than developing countries, thus assuming larger proportions and having wider ramifications. In this context, a new impetus has been given to the G20, and against this background, several studies have sought to understand not only the crisis but the role of a reformed G20 in the process of resolving it (DERVIS and DRYSDALE, 2014; HELLEINER, 2014; LUCKHURST, 2016). Despite the relevance of this literature, little attention has been paid to the G20 outreach process, particularly to the growing dialogue established between the G20 and B20 (Business Summit 20), a group that represents the business sector in such exchanges.

Parallel to this question, since the 1970 s and 1980s a rich literature has sought to understand processes in the transnationalization of relations of production, circuits of accumulation and, a result of these, of the forces of production. In this context, concepts have arisen such as transnational capitalist class and networks of corporate elites, that seek to empirically understand the processes through which this class, class fraction and/or elite network is constituted and articulated (APELDOORN and GRAAFF, 2014; CARROLL, 2010; FENNEMA, 1982; GRAAFF and APELDOORN, 2017; HEEMSKERK, et al., 2015; PIJL, 1998; ROBINSON, 2010; SKLAIR, 2001). The present article seeks to establish a dialogue between the propositions around a transnational capitalist class and the B20 as a forum that serves as a space for the interaction of global corporate elites.

To do so, it presents an exploratory analysis of the relations between the B20 and the G20 in the period between 2010 and 2017 and their ramifications, so 
as to better understand processes of the transnationalization of the capitalist class. We thus start from two, broadly complementary, hypotheses. The first is that, during this period, it is possible to identify the constitution of a 'B20 Nucleus', formed of companies and individuals present at most B20 summits, which are largely based in the North Atlantic countries. This would tend to support Carroll's (2010) arguments about the transnational capitalist class as a largely Atlanticist group. The second hypothesis is that the B20 acts as a point of integration for the global corporate elite, an argument in line with those made by Carroll and Carson (2003) and Carroll (2010) on the role of policy-making forums in the global corporate network.

The article is therefore structured as follows. First, we present a theoretical discussion that grounds our hypotheses, focusing on the concepts of the transnational capitalist class (TCC) and transnational state (TNS). Second, in order to contextualize the B20, we offer a brief description of the process through which the G20 was constituted and of the organization's structure. This is followed by a discussion of the B20 - providing a brief history, with an emphasis on its structure, changes since 2010 and its regional and country-level representation, as well as the sectors that are represented within it. Fourth, we will explore the relationships between the B20 and G20, emphasizing the points of convergence between the agendas of the two forums. To conclude, we offer some final exploratory comments about the role of the B20 as locus of interaction for the capitalist class and how it relates to the reproduction of the hegemony of the globalist historical bloc.

\section{The transnational capitalist class and the transnational state}

The emergence of a capitalist class in the international arena has been debated for decades. With the intensification of globalization processes beginning in the 1970s, the debate gained new momentum, and the focus shifted towards a transnational process of (trans)formation of the capitalist class (ROBINSON and HARRIS, 2000). For van der Pijl (1998) this process was historical, coinciding with the stages of internationalization of capital itself. In this way, the initial appearance of a TCC was intertwined with the global expansion of trade, passing through the internationalization of financial capital and the consequent emergence of high finance. This connected bankers, leading to the emergence of a transnational managerial class in the post-World War II period that was responsible for the 
management of multinational corporations that arose through the internationalization of production (PIJL, 1998).

In this way the TCC was initially understood as a transatlantic phenomenon, bringing together fractions of the capitalist class originally from the USA and Western Europe (PIJL, 1998), though it gradually sought a broader base through the inclusion of Japan, mainly through of the Trilateral Commission (GILL, 1990) ${ }^{1}$. However, as globalization of production and capital flows intensified and spread beyond Atlantic circuits beginning in the 1970s, the TCC came to encompass "segments of national bourgeoisies and state bureaucracies in a series of countries that have material interests in the relatively free flow of capital, goods and services within the world economy" (GILL, 2003, p. 86). However, to the extent that production and finance circuits themselves became transnational, so did classes, which would use such circuits as points of articulation (RAMOS, 2013; ROBINSON and HARRIS, 2000). As a consequence, this process of building a transnational system of investment and production led to the emergence of a transnational capitalist class. Thus, as Harris (2014) states, this class “...materializes from the historical movement of capitalism itself, and consolidates itself through the necessity of expanding the conditions of its own existence" (HARRIS, 2014, p. 732).

This process, as Robinson (2015) argues, did not occur in a unique and total way: “'varieties of capitalism' produce 'varieties of integration' to global capitalism” (ROBINSON, 2015, p. 17). But in broad terms, strata of national capitalist classes remained oriented toward domestic production, while a distinct fraction became oriented towards the transnational sphere. Such groups often overlap and compete over different development strategies. Thus, according to this literature, the idea of a TCC does not necessarily imply that national or regional capitals have come to an end, or that the TCC is fully cohesive and free of conflict. What happens

\footnotetext{
${ }^{1}$ The Trilateral Commission emerged in 1973 in this context of intensified globalization. This forum aimed to "[...] promote effective collaborative leadership in the international system and closer cooperation between the major capitalist regions of Northern Europe, North America and Japan the 'triad'. It continues a tradition of consultation within the ruling class, bringing together transnationalized fractions of the business, political, and intellectual elite during several annual meetings that occurred at the national, regional, and plenary levels" (CARROLL, 2010, p. 42). For a critical study of the Trilateral Commission, see Gill, 1990.
} 
is that the transnational fraction of capital has become hegemonic across a large part of the world, acting as a coherent political actor without national identity, and often conflicting with national fractions of capital (ROBINSON, 2010, 2007, 2005a; ROBINSON and HARRIS, 2000).

As Robinson and Harris (2000) argue, this TCC is essentially composed of the owners of transnational capital, ie. the world's main means of production transnational corporations and private financial institutions. Gill (2003) adds to this bloc some of the main politicians and civil servants of both the core capitalist countries and some of the least developed countries. In this context, Sklair (2002, 2000) identifies four fractions or groups that are interconnected within the TCC: 01. owners and controllers (executives) of transnational corporations and their local affiliates - the corporate fraction; 02. global bureaucrats and politicians - the state fraction; 03. global professionals - the technical fraction; and 04. traders and the media - the consumer fraction. The author clarifies that, despite the disparate functions of each group, individuals commonly move between fractions - "Key individuals can belong to more than one fraction at a time, and the shift from one group to another is more or less routine in various societies" (SKLAIR, 2002, p. 160). For Harris (2014), meanwhile, there is a fifth fraction within the TCC: constituted by the industrial/military complex, which has its own more and less global wings (HARRIS, 2014).

The TCC is understood as being at the center of attempts to construct a new historical bloc ${ }^{2}$, composed of economic and political forces guided by transnational

\footnotetext{
${ }^{2}$ For the authors cited here, the notion of a historical bloc is derived from Gramsci. In this understanding, a historical bloc first points to a reciprocal relationship between structure and superstructure, that is, "[...] ideas and material conditions are always found together, mutually influencing each other and not reducible to one another" (RAMOS, 2013, p. 97). Second, the conception of a historical bloc "[...] indicates the integration of a variety of different class interests and forms of identity within a 'national-popular' aliance" (MORTON, 2007, p. 97). In other words, for the purposes of this article, a historical bloc is understood as being constituted via the hegemony of a social class within the state and civil society, maintaining cohesion and identity within the bloc through the propagation of a common culture (MORTON, 2007).
} 
processes of accumulation and production, thus constituting a 'globalist bloc' (ROBINSON and HARRIS, 2000). This bloc must be understood as part of a project of transnational hegemony ${ }^{3}$ and, in this sense, as one that is incomplete and contested (ROBINSON, 2005b). To some extent, Robinson (2005b) argues, the globalist bloc achieved a degree of hegemony during the 1980s and 1990s, due much more to the disarticulation of popular classes around the world than of the internalization of support for neoliberalism among broad sectors of society at a global scale. Although it cannot be denied that such internalization did occur across different social sectors around the world during this period, in many cases this occurred via the use of force, as in the case of many post-Soviet republics, for example. By the end of the 1990s, it was possible to perceive that the globalist bloc was in crisis, reflecting the instability of the financial sector - a fact that reached its full expression in 2008. Since then the bloc has been cracking, but as Robinson says, "[...] transnational capital is not reverting into national capital. Rather, the TCC is turning to the construction of a permanent war economy and a global police state to counter the explosive contradictions of uncontrolled global capitalism" (ROBINSON, 2017, p. 173).

Robinson (2017) identifies important mechanisms used to overcome these contradictions in his controversial concept of transnational state (TNS). Debates on the TNS revolve around Cox's $(1981 ; 2002)$ concept of the internationalization of the state and Gill's $(1990 ; 2003)$ of transnationalization of the State, which refer in general terms to the growing integration between government agencies, corporations embedded in the global economy and institutions of global governance. This process, according to Cox (2002), should be understood as:

"[...] official and unofficial transnational and international networks of the representatives of states, corporations and intellectuals working to formulate a political consensus for global capitalism as a 'nébuleuse' - something that does not have a fixed official institutional

\footnotetext{
${ }^{3}$ The idea of hegemony used here also comes from the Gramscian tradition. Hegemony is understood as "[...] the way in which a dominant group establishes and maintains its authority. Hegemony is government by consent, or cultural and intellectual leadership achieved by a particular class, class fraction, stratum or social group, as part of a larger project of class rule or domination" (ROBINSON, 2005b, p. 560).
} 
structure, but which emerges from discussions in bodies such as the Trilateral Commission, the World Economic Forum in Davos, the regular meetings of representatives of the OECD, IMF, World Bank and WTO central banks, the G7 and G8 summits, and their preparatory meetings" (COX, 2002, p. 33).

The transition from the term internationalization to transnationalization proposed by Gill $(1990 ; 2003)$ - was not merely a semantic matter, since it sought to highlight the importance of the actors involved in this process (RAMOS, 2013). In this way, the transnationalization of the state, “[...] a process whereby state policies and institutional arrangements are conditioned and altered by the power and mobility of the transnational fraction of capital" (GILL, 1990, p. 94) is facilitated by key individuals within the state apparatus that connect to networks of international interests "[...] represented in institutions [...] [which are] part of an informal structure of international influence" (GILL, 1990, p. 95).

It is from this conceptualization of the impacts of processes of globalization for the exercise of political power in the world that Robinson and Harris (2000) assert the agency involved in the transnationalization of the State through the activities of the TCC. According to these authors, "The TCC directly instrumentalized the apparatus of the TNS, exercising a form of transnational state power through the configuration of various levels of the TNS. It is through these global institutions that the TCC has attempted to forge a new global capitalist hegemonic bloc" (ROBINSON; HARRIS, 2000, p. 11). This process stems from the fact that the supranational legal and regulatory system built over the last few decades - embodied in international organizations and political forums - has, in order to ensure the maintenance and reproduction of the global economy, sought to keep its political prescriptions synchronized with those national states in which transnational-oriented elites achieved hegemony (ROBINSON, 2010). A transnational state apparatus was thus constituted, in which its institutions sought to coordinate global capitalism, as well as guaranteeing capitalist expansion beyond national boundaries (ROBINSON, 2010). In this way, the TNS apparatus can be defined as “...a loose network composed of inter- and supranational political and economic institutions, together with the apparatuses of national states that have been penetrated and transformed by transnational forces, and which have not yet acquired (and can never acquire) any centralized form" (ROBINSON, 2010, p. 10). 
This process of the internationalization/transnationalization of the state (which led Robinson and Harris (2000) to propose the concept of the TNS) is central to our topic because it is from there that the forums for policy formulation gain prominence. These forums are kinds of hubs for the global corporate elite, acting "within an incipient 'global civil society' that is distinct from both state power and economic power, but closely linked to both. It is from these points that strategic and moral visions, as well as politics, are forged, informing transnational capitalist interests" (CARROLL and CARSON, 2003, p. 31). Examples of policymaking forums of this type are the World Economic Forum, the Trilateral Commission and the International Chamber of Commerce (ICC) - although there are several others 4 . These forums "[...] play an integrating role, bringing together corporate directors and capitalist interests from various parts of the global system" (CARROL and CARSON, 2003, p. 48). Furthermore, the policy formulation forums are part of the transnational state apparatus, in which objectives are agreed upon and decisions for the global economy taken (HARRIS, 2014), helping to create consensus around one or other variant of neoliberal discourse (CARROLL and CARSON, 2003). In short, "[...] they are agencies of political and cultural leadership, whose activities form an integral part of the formation of a transnational capitalist class" (CARROLL and CARSON, 2003, p. 53).

These forums are, therefore, important spaces for the articulation of global corporate networks, which in turn are taken as evidence of the formation of a TCC as several studies have argued in recent years (CARROLL, 2010; HEEMSKERK, FENEMA and CARROLL, 2015; HEEMSKERK and TAKES, 2015; STAPLES, 2006). The regular meetings of these forums contribute, among other things, to bring together the boards of the world's leading corporations, integrating them into a global corporate elite (CARROLL and CARSON, 2003). In his seminal study, Carroll (2010) identifies the existence of a global corporate network constituted by the world's top 500 corporations. In this network the policy-making forums "[...] provide a politically and socially active hard nucleus to the global corporate network"

\footnotetext{
${ }^{4}$ In addition to the groups mentioned above, Carroll (2010) also highlights: the Bilderberg Conference, the International Advisory Board of the Council on Foreign Relations, the World Business Council for Sustainable Development, the UN Global Compact, the European Round Table of Industrialists, the EU-Japan Business Round Table, TransAtantic Business Dialogue, and the North American Competitiveness Council.
} 
(CARROLL, 2010, p. 192). This is largely due to the mediation role (BURT, 2004) played by such forums - in that they bring together parts and nodes of the network that are not directly interconnected. In this way, the forums for policy formulation have over recent decades consolidated as integration points in the global corporate power structure (CARROLL, 2010).

Starting from such a conceptualization, our argument is that the B20 can be understood as another point of integration for the global corporate elite, and which, as such, contributes to the formation of a transnational capitalist class. However, it is necessary to explain in a more specific way what role is played by the B20 in this process. To this end, we will outline the activities and structure of the B20, a discussion that will provide us with firmer foundations to support this argument.

\section{Methodological note}

To delineate the processes from which we can infer the respective agendas of the B20 and the G20, we started by conducting document and content analysis, with emphasis on documents containing these groups' recommendations and declarations. A wide range of official documents was used to survey the companies, organizations and individuals present in the activities of the B20. At the end of such documents, these participants are typically listed. Their country of origin is defined based on the country in which headquarters are located. Exceptions to this procedure are international organizations such as the OECD and the UN, which are not considered to have national links. The names of the key B20 individuals have been identified because the information consulted is already in the public realm.

\section{Contextualizing the B20: emergence and structure of the G20}

The G20 emerged from the G7/85 in 1999 to deal with the development and effects of the Asian financial crisis. The crisis, which began in the countries of East Asia, eventually contaminated several countries, including Brazil, Russia and Argentina. Among the different proposals within the G7/8 for expanding dialogue around global financial governance, it was that put forward by the US and Canada

\footnotetext{
${ }^{5}$ The G7/8 is composed of the USA, France, Italy, Germany, the UK, Canada and Japan, plus Russia. In 2014 Russia was suspended due to tensions over the conflict in Ukraine. For an analysis of the G7/8 system see Ramos (2013).
} 
that prevailed. The idea was to create a more representative group with a greater number of US allies to counteract what the US saw as an over-represented European bloc. The initial criteria for choosing new members was GDP, population and participation in world trade, but the US forced the inclusion of some of its allies, including Australia, Argentina, Saudi Arabia and South Korea. The list of invited countries was quickly submitted and approved by the G7 (CAMMACK, 2012; CARIN et al, 2010; WADE, 2011).

Between 1999 and 2007, G20 meetings only took place at the ministerial level. Initially two vice-ministerial meetings were held with central bank directors and the international secretaries of economics ministries, and a ministerial meeting at the end of each year involving finance ministers and central bank presidents. However, as it became clear that the effects of the Asian crisis would not cause more serious damage to the Western powers, G7 finance ministers began to lose interest in G20 meetings. In this way, over much of this period, the G7 countries ended up being represented only by lower-ranking officials and ministers (VIANA and CINTRA, 2010; WADE, 2011).

However, a new financial crisis changed the outlook for the G20. In 2008, the center of global capitalism was shaken by the worst crisis since 1929. In the face of a crisis with wider effects than the Asian crisis had had, the G20 gained new momentum as the perception grew that only by meaningfully incorporating emerging and developing countries into international financial governance would it be possible to overcome the crisis. In order to deal with the crisis of 2008, the G20 was reconstituted at a leaders' summit, holding ministerial and ministerial meetings as preparatory meetings, thus giving greater weight to the forum (RAMOS, 2013; VIANA and CINTRA, 2010).

The G20 encompasses the world's leading advanced and developing economies. Currently the group represents two-thirds of the world's population, $85 \%$ of global GDP and around 75\% of global trade. The G20 countries are Canada, France, Germany, Italy, Japan, the UK, the USA, Russia, China, India, Indonesia, Mexico, South Korea, Turkey, Argentina, Australia, Brazil, Saudi Arabia, South Africa, and the European Union (represented by the President of the European Council and the head of the European Central Bank). At each summit several 
countries are invited to ensure that all regions of the world are represented. Spain, for example, was elevated to the status of permanent guest due to its continual participation in the summits following the 2008 crisis. In addition, the president of the Association of Southeast Asian Nations (ASEAN), the Global Governance Group, two African countries - usually the president of the African Union and a representative of the New Partnership for Africa's Development (NEPAD) - and one or more countries from the same region as the host country are also invited to each summit. As well as the various countries, the following international organizations also participate in the summits: the Financial Stability Board (FSB), International Monetary Fund (IMF), International Labour Organization (ILO), Organization for Economic Co-operation and Development (OECD), United Nations (UN), World Bank and World Trade Organization (WTO) (G20, 2015b, 2015c, 2015d; GEGAFRICA, 2015).

Since 2008 G20 activities reach a climax at the Group's annual summit. Over the course of a year of activities, under the rotating presidency of one of its members, the G20 is organized into thematic taskforces that vary in number and scope. Issues such as financial architecture and regulation, employment, infrastructure investments, Bretton Woods institutions (IMF and World Bank) and stimulus for small and medium-sized enterprises are always present, and the activities of these taskforces give rise to the reports that serve as the basis for the final declaration of G20 leaders. This question is pertinent to our objectives because, as it will be explored later, it is at the summits, and in their relations with the taskforces, that the B20 seeks to project their interests.

Since 2008 the G20 has undergone a process of outreach, in two directions in particular: 01. an expansion in its thematic focus; and 02. an expansion of engagement with civil society groups. Regarding the first, over the course of the leadership summits the G20 gradually incorporated new themes into its agenda. Topics such as sustainable energy, food security, climate change, combating corruption and tax evasion, and information technologies, as well as geopolitical tensions (the Syrian civil war, Ebola, the refugee crisis) have been addressed by the forum. As for the second area of outreach, it should be noted that dialogue with civil society groups was already taking place within the framework of the G7/8 through initiatives such as Civil G8 and Think G8 or through direct dialogues with 
NGO representatives, efforts that have continued under the G20 since its reconstitution (HAJNAL, 2015). However, what we observe is a formalization of dialogue through the formation of independent groups within the sphere of the G20. These groups issue their own reports containing recommendations for the G20 leaders ahead of leaders' summits. In 2013 the G20 officially recognized these dialogue groups and committed to strengthening their relationships with them. According to the G20, its involvement with such dialogue groups “[...] has grown over the years, reflecting the important role of the nongovernmental sector in ensuring post-crisis recovery" (G20, 2014b, p. 01).

There are currently six dialogue groups linked to the G20: Civil 20, which engages with representatives of various NGOs around the world; Think 20, which is responsible for dialogue with think tanks in the G20 countries; Labor 20, organized by the Trade Union Confederation (ITUC) and the Trade Union Advisory Committee (ITUAC) with the aim of bringing recommendations from the labor sector to the G20; Youth 20, a platform for young people from the G20 countries to have a voice in the forum; Women 20 , whose main objective is to assist in the implementation of the G20 commitments relating to women; and Business 20 , which is responsible for defending the interests of the business sector within the G20 - the subject to which we turn in the next section.

\section{Business Summit 20}

\section{History and structure}

The B20 held its first official meeting in 2010 at the Toronto Summit. However, the articulation of businesses around the G7/8 and the G20 predate this. In fact, since the G7 summit in Houston, 1990, the ICC president has met with representatives of the host country a few weeks before the leaders' meeting. In the context of the G20, there has been direct contact with the business sector since the first summit in Washington in 2008. On these occasions, representatives of the business sector, mostly from confederations, federations and business councils, meet prior to the leaders' summits for discussions and to produce a document containing recommendations for the G20. However, initially the 
recommendations of the business sector still had a superficial character, lack explicit engagement and articulation of - and with - the G20, a scenario that changed in 2010 (RAMOS, 2013).

In 2010, at the Toronto Summit, the B20 began to assume its current shape. The Canadian Council of Chief Executives, with the support of the Canadian government, organized a meeting of executives from large companies in the G20 countries. The meeting took place one day before the leadership summit and was attended by two representatives from each G20 member. The aim was to "give voice to business communities in member countries and provide advice on policies affecting business and industry" (CARIN et al., 2010, p. 12). At the meeting a document containing a series of generic recommendations was sent to the G20 and a subsequent meeting was scheduled to take place a few months later at the Seoul Summit, which would consolidate the integration of the private sector into the G20 process.

In methodological terms, the Seoul Summit can be understood as a crucial causal mechanism, as from this point the B20 came to take its current shape. Subsequently, the B20 has established its activities around taskforces that gather for activities over the course of the year, culminating in the formulation of recommendations that are delivered to the G20 before each leadership summit. These taskforces meet in person and/or by videoconference once or more per year. The number of taskforces and their themes vary over each year of B20 activities, though not dramatically. The group's agenda is not much different from the G20's, as the B20 attempts to incorporate into its actions and recommendations into the priorities set by the rotating presidency of the G20, thereby increasing its ability to engage with and influence it. The number of people involved in B20 activities has grown considerably over the years, from just over 120 in Seoul to more than 700 executives and directors in Hamburg in 2017. The number of companies and organizations represented in B20 activities has also increased. In Seoul there were 119, whereas in Hamburg there were 547 companies and organizations (see Chart 01).

It is worth noting that the B20 maintained a close relationship with trade and business organizations. Two trends can be identified. The first is the active participation of local employers' federations and confederations, as well as 
associations and chambers of commerce, in organizing and supporting group activities: in Seoul, the Federation of Korean Industries, the Korean International Trade Association and the Korea Chamber of Commerce and Industry (B20, 2010a); in Cannes, MEDEF (Mouvement des Entreprises de France) (B20, 2011); and in St. Petersburg the RSPP (Russian Union of Industrialists and Entrepreneurs), to cite a few examples (B20, 2013).

Chart 01. Number of companies/organizations present at the B20 meetings between 2010 and 2017

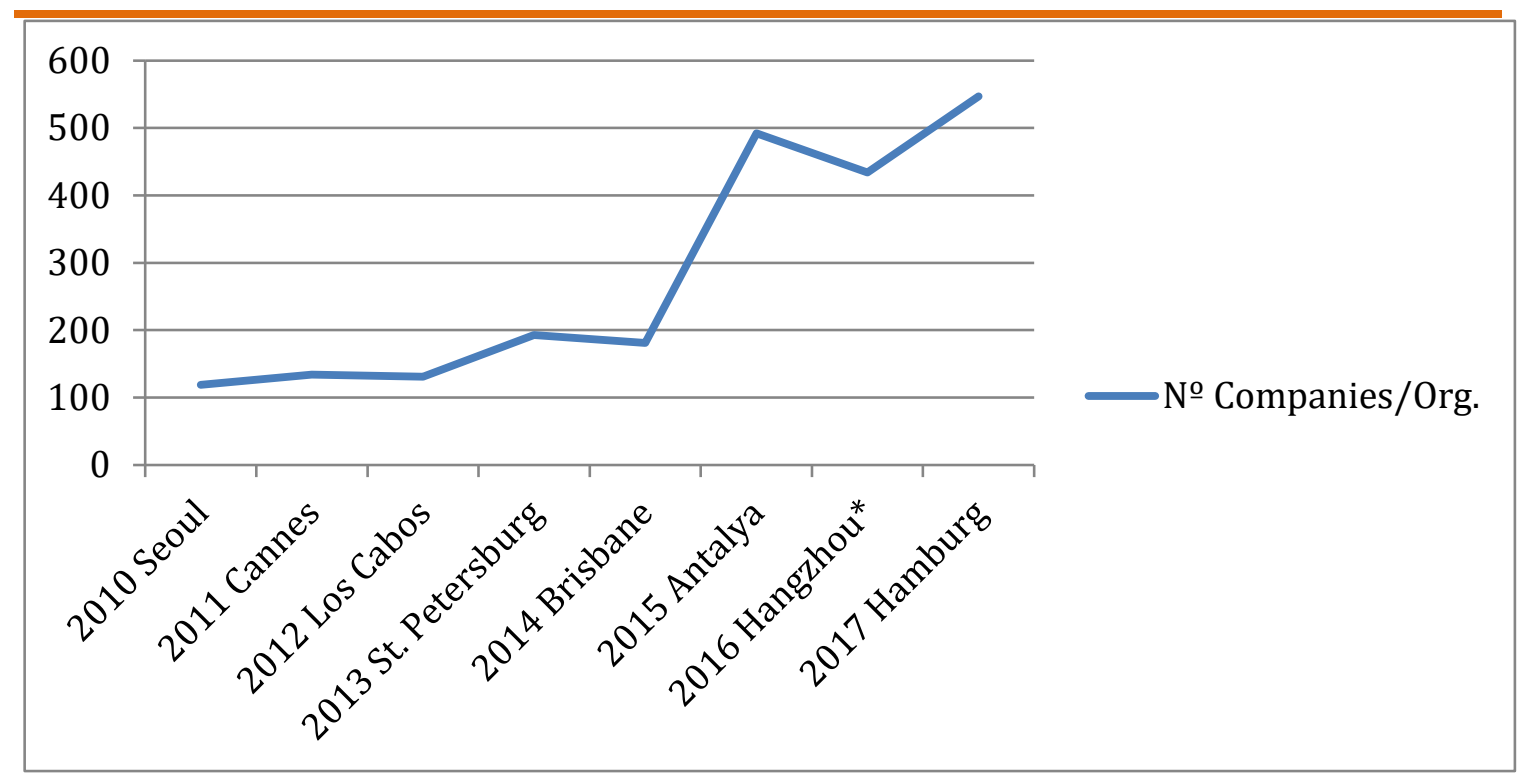

Notes: * Because some taskforces in Hangzhou did not provide the number of participants in their activities, the total number of companies and organizations involved in B20 activities in 2016 may have been higher than the data presented here.

Source: Elaborated by the authors, based on B20 documents.

The second trend is the direct involvement of other policymaking forums and consultancy firms in the organization of the B20 meetings. The ICC is a longstanding partner of the B20, as is clear from the words of ICC executive Harold McGraw III and director of McGraw Hill: "[...] ICC has historically articulated the priorities of business to G20 leaders, and has served as a strategic partner for B20 national hosts in developing policy recommendations for consideration by the G20 [...]" (ICC, 2015). The World Economic Forum has also been directly involved with the B20, as can be seen in the reports of the taskforces in Cannes, Los Cabos and Saint Petersburg (B20, 2013, 2012, 2011). Management consulting firms also have a close relationship with the B20, something that can be seen mainly at 
the Cannes summit, where McKinsey \& Company was a recognized partner in all the taskforces (B20, 2011). In fact, the proximity between B20 and the major management consulting firms can also be seen in the growing representation of such companies within the B20 (see Chart 02).

Chart 02. Number of companies/organizations at B20 meetings between 2010 and 2017, by region

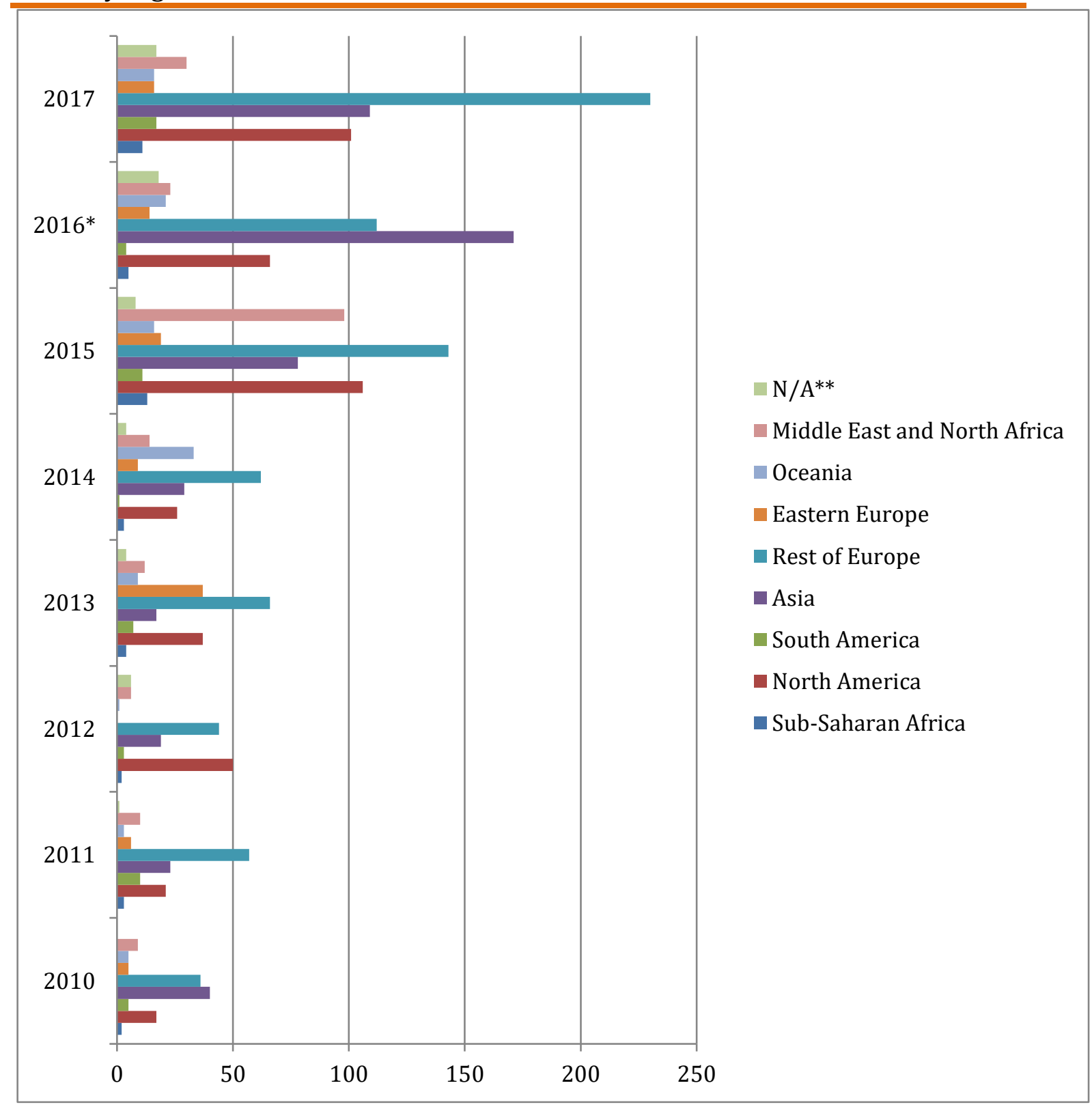

Notes: ${ }^{* *}$ This category contains international organizations and companies/organizations whose origin could not be identified.

Source: Elaborated by the authors, based on B20 documents. 


\section{Membership and representativeness on the B20}

Since the Seoul Summit, representation by country has not followed preestablished rules. In other words, official G20 membership does not guarantee a country representative status on the B20. This is exemplified by the absence of companies and organizations based in Mexico at the Brisbane 2014 summit, in Japan and Russia at the 2012 Los Cabos summit, in Indonesia at the Cannes 2011, Los Cabos 2012 and St Petersburg 2013 summits.

In Antalya, Turkey, in 2015, the B20 initiated a movement that sought to expand representation. For the first time, regional consultations were held to discuss the B20's recommendations to the G20 with local business communities. A total of 11 consultations took place on 04 different continents - including one in São Paulo chaired by the Brazilian Confederação Nacional da Indústria (National Confederation of Industry, CNI) - bringing together a total of 950 individuals from public and private organizations (B20, 2015c). Related to this, Since Antalya there has been a significant increase in the number of companies and organizations present at B20 activities.

Looking at Charts 02 and 03 , it is possible to identify some patterns in terms of national and regional representation within the B20 over time. First, there is a massive presence of companies/organizations based from the country hosting a given G20 summit. On average, the host country represents almost $20 \%$ of the total number of companies and organizations participating in B20 activities. Second, the USA - with an average of $13.8 \%$ of companies/organizations across the different summits - and France - with an average of 8\% - had significant representation at all the summits analyzed, both being among the top five countries with in terms of companies present across all 08 summits. Third, there is a predominance of North Atlantic companies/organizations, though presence of Asian companies/organizations is also significant. In this scenario, France, Germany and the United Kingdom stand out in Europe; USA in North America; and China, India and South Korea in Asia. 
Chart 03. Main countries of origin of companies/organizations, by summit (\%)

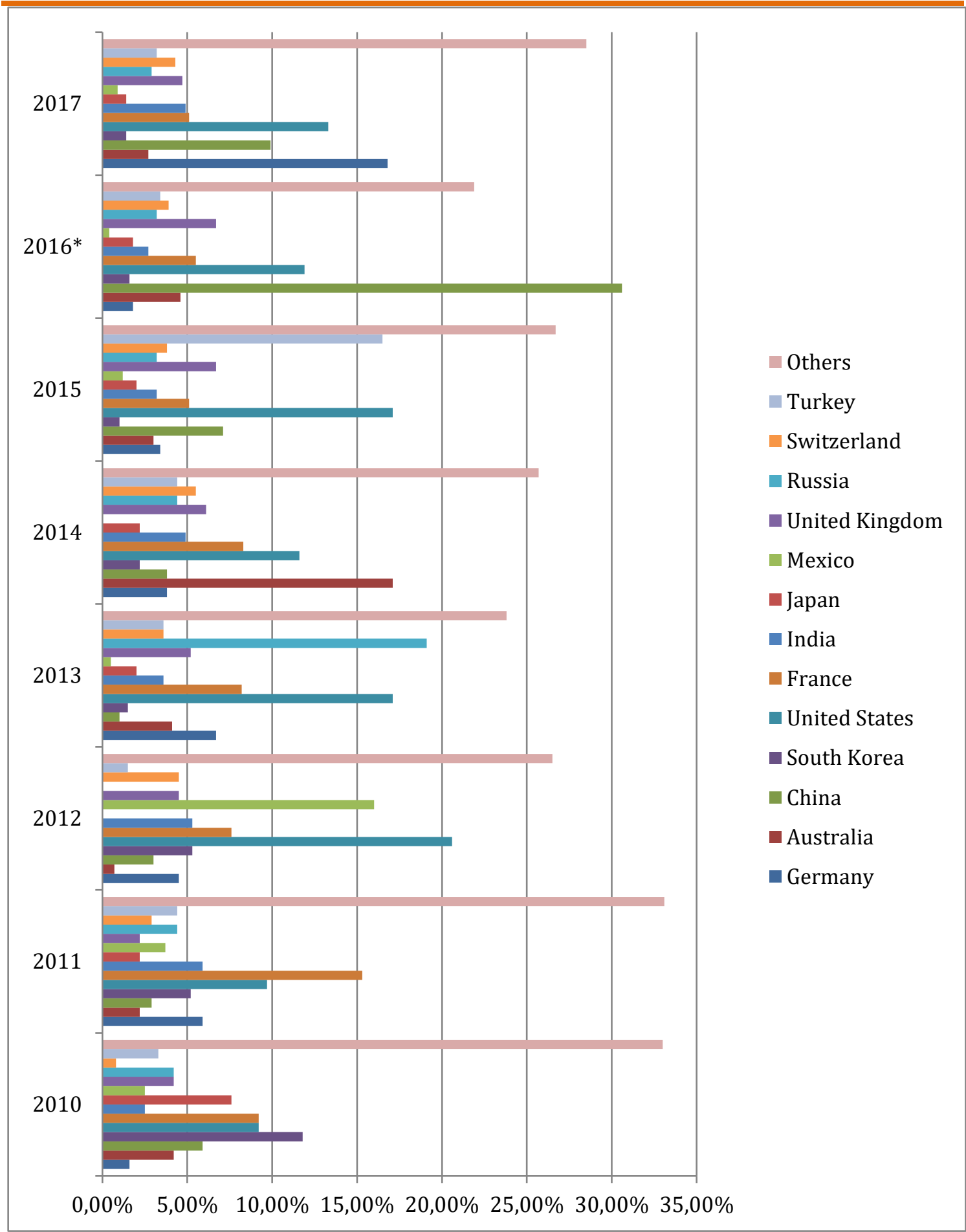

Notes: * Because some taskforces in Hangzhou did not provide the number of participants in their activities, the total number of companies and organizations involved in B20 activities in 2016 may have been higher than the data presented here.

Source: Elaborated by the authors, based on B20 documents 
Chart 04 provides an overview of the types of companies and organizations represented at the B20, showing that a wide range of sectors is included. As with country representation, the B20 does not have rules about which sectors should be represented, but it is still possible to identify some patterns across the summits analyzed. First, three sectors stand out for their high levels of participation: 01. Federation/chamber/organization, which comprised, on average, 23\% of total companies across the summits; 02. Bank/finance/insurance with an average of close to 22\%; and 03. Conglomerates/holdings with an average of $8 \%$. Second, participation by the management consulting/HR sector gradually increased, becoming one of the main sectors at the 2014 Brisbane Summit. Third, some sectors have always been present at B20 summits, such as the three mentioned above, as well as Steel/metallurgy/mining, Agriculture/agribusiness, Food, Computing/software/IT, Construction/engineering, Law, Energy, Logistics/express shipping, Oil/gas, Chemicals and Telecommunications.

This data also highlights another trend: the existence of a group of companies/organizations, and their respective sectors, that were present at least seven of the eight summits analyzed. As several of these companies were represented by the same individual across these summits, it is also possible to identify directors/executives with this high level of participation. In this way it is possible to observe the formation, over these years, of a 'B20 nucleus' - as shown in Table 01.

The data presented and discussed so far allow us to make some initial inferences: 01 . the composition of the B20 is mainly made up of representatives of companies/organizations from the North Atlantic and from the country that is hosting the G20 and B20 activities in a given year, though there is also significant participation of companies and organizations from Asia; 02. as such, for almost a decade the B20 has been consolidating as an important point of interaction between local and regional elites with North Atlantic elites, operating as an important locus of the (re)construction, maintenance and transmission of hegemony on a transnational scale; 03. despite the significant participation of Asian companies and organizations, it is possible to identify a B20 nucleus composed of 32 companies, mostly from the North Atlantic, as well as seven executives and directors, mostly 
from Europe; 04. South American and Sub-Saharan African companies/organizations are not represented in the B20 nucleus. To some extent, this is an interesting finding in light of arguments about the supposed emergence of the Global South - in other words, the idea of a 'B20 nucleus' offers empirical evidence that suggests a need to rethink this hypothesis (KIELY, 2015; PIJL, 2017).

Table 01. The B20 nucleus - Present at seven or more summits

\begin{tabular}{lccccc}
\hline $\begin{array}{l}\text { Country of origin } \\
\text { of company/organization }\end{array}$ & № & $\begin{array}{c}\text { Nationality of } \\
\text { executive/diretor }\end{array}$ & № & Sector & № \\
\hline USA & 06 & French & 02 & Federation/chamber/organization & 08 \\
Spain & 04 & Spanish & 01 & Bank/finance/insurance & 05 \\
France & 03 & Swedish & 01 & Steel/metallurgy/mining & 03 \\
Italy & 02 & Russian & 01 & Conglomerate/holding & 03 \\
UK & 02 & Australian & 01 & Energy & 03 \\
Switzerland & 02 & Argentinian & 01 & Management consulting/HR & 02 \\
South Korea & 02 & - & - & Oil/gas & 02 \\
Russia & 02 & - & - & Chemicals & 02 \\
Canada & 01 & - & - & Food & 01 \\
Germany & 01 & - & - & Construction/engineering & 01 \\
Netherlands & 01 & - & - & Law & 01 \\
Sweden & 01 & - & - & Telecommunications & 01 \\
China & 01 & - & - & - & - \\
India & 01 & - & - & - & - \\
Australia & 01 & - & - & - & - \\
Saudi Arabia & 01 & - & - & - & 32 \\
N/A & 01 & & & Total \\
Total & 32 & Total & 07 & & \\
\hline
\end{tabular}

Source: Elaborated by the authors, based on B20 documents.

\section{Some inferences about the B20-G20 relationship}

So far we have tried to present some inferences about the B20, based on descriptive research on the B20 and the identification of certain causal mechanisms underlying it. We now turn to another question, namely the relationship between the B20 and G20. A closer look at the B20's supporting documents and statements made by G20 leaders reveals common themes and helps us pinpoint mechanisms that produce consensus between the two groups. It is important to emphasize that the fact that a theme or action recommended by the B20 is present in the G20 declaration does not indicate that the G20 adopted it under the exclusive influence of the B20. It is not a question of establishing a direct causal relationship between the B20 and G20, but rather of identifying certain mechanisms in the analytical process - which are summarized in Table 2 and explained below. 
Chart 04. Main sectors represented, by summit (\%)

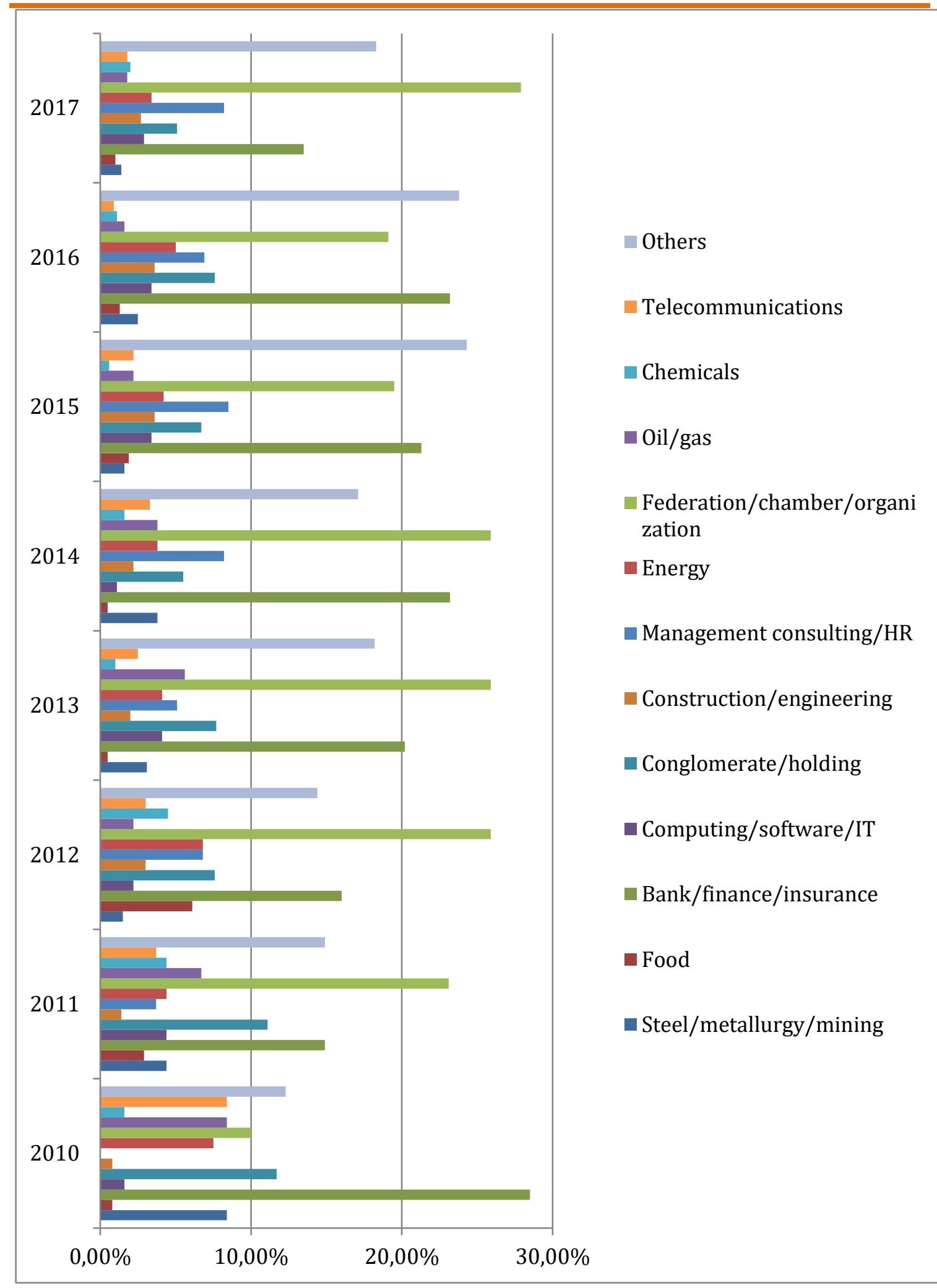

Notes: * Because some taskforces in Hangzhou did not provide the number of participants in their activities, the total number of companies and organizations involved in B20 activities in 2016 may have been higher than the data presented here.

Source: Elaborated by the authors, based on B20 documents. 
Looking at the documents that contain the B20's recommendations to the G20 alongside statements made by the G20 leaders, there is a striking similarity between the agendas of the two forums. The consensus is not restricted to the topics covered, but can also be seen in support for the recommendations within the G20 and their materialization into concrete commitments. In this way, four issues stand out with regard to B20 activity and its relationship to the G20. Firstly, the themes addressed by the B20 during the eight summits analyzed do not undergo major changes from one year of activities to the next. What can be seen from the inclusion and/or removal of taskforces (Table 02) is a shift of focus between G20 presidencies, but not significant changes in the B20 agenda.

Table 02. Changes in the B20 taskforces compared to previous summit

\begin{tabular}{|c|c|c|}
\hline Summit & № of Taskfores & Changes from previous summit* \\
\hline 2010 Seoul & 12 & \\
\hline 2011 Cannes & 12 & $\begin{array}{c}\text { New taskforces: } \\
\text { - Information technology, } \\
\text { - Corruption } \\
\text { - Food Security. }\end{array}$ \\
\hline 2012 Los Cabos & 07 & $\begin{array}{c}\text { Taskforces removed: } \\
\text { - Commodities and raw materials } \\
\text { - Global governance } \\
\text { - Energy }\end{array}$ \\
\hline 2013 St Petersburg & 07 & $\begin{array}{c}\text { New taskforces: } \\
\text { - Efficiency of G20-B20 dialogue } \\
\text { - Financial system } \\
\text { Taskforces removed: } \\
\text { - Green growth } \\
\text { - Food safety } \\
\text { - Information technology }\end{array}$ \\
\hline 2014 Brisbane & 05 & $\begin{array}{l}\text { Taskforces removed: } \\
\text { - Efficiency of G20-B20 dialogue } \\
\text { - Innovation and development }\end{array}$ \\
\hline 2015 Antalya & 07 & $\begin{array}{c}\text { New taskforces: } \\
\text { - Digital economy } \\
\text { - Small and medium-sized } \\
\text { businesses }\end{array}$ \\
\hline 2016 Hangzhou & 06 & $\begin{array}{l}\text { Taskforces removed: } \\
\text { - Digital commerce }\end{array}$ \\
\hline 2017 Hamburg & 09 & $\begin{array}{c}\text { New taskforces: } \\
\text { - Digitalization } \\
\text { - Energy, Climate and Resource } \\
\text { efficiency } \\
\text { - Health }\end{array}$ \\
\hline
\end{tabular}

Notes: * Changes correspond to the taskforces included or removed from a summit, in relation to the previous one. "Removal" does not necessarily mean that a particular topic was not discussed by the B20, as themes are often incorporated into a other taskforces. Source: Elaborated by the authors, based on B20 documents. 
Secondly, there are themes of greater consensus between the B20 and the G20. At most summits, and in some cases in 'all' the summits analyzed, the following themes were present in both the B20 recommendations and the G20 leaders' statement: the need for investment incentives, especially in infrastructure; concerns about protectionist measures, mainly non-tariff barriers; discussions in the WTO, especially with regard to the Bali agreements; sustainable energy and investments in the sector; financial regulation; greater representativeness of emerging countries in the IMF; small and medium-sized enterprises, in particular their sources of funding; and the fight against corruption, especially concern about tax evasion and processes for discussing the subject at the OECD and UN levels.

Thirdly, some of the B20 recommendations at the summits analyzed can be identified as 'achievements' of the forum. Five are worth mentioning: 01. establishing a B20-G20 dialogue on the fight against corruption. Although there has not yet been any G20 commitment to increasing private sector involvement in the discussions of the OECD working group on bribery, the B20 has been promised that private sector representatives will be included in discussions at the UN Convention against Corruption. Still, during the five summits, the G20 made several mentions to the B20's engagement on the subject; 02. the B20 consistent interest in small and medium-sized enterprises and their sources of financing. This theme was present at all the summit analyzed, with references and commitments also made by the G20 at all of these summits with the exception of Brisbane. In Antalya, the B20 was able to win support and recognition from the G20 for the World SME Forum (for small and medium-sized enterprises). This question points to the importance of the active participation of local federations and confederations, as well as associations and chambers of commerce, in organizing and supporting the activities of the group, which end up making certain demands in the interest of its members; 03. with the exception of the Brisbane summit, there has been some agreement between the B20 and the G20 on the reduction of subsidies for fossil fuels; 04. associated with point (02), the Global Infrastructure Hub (GI Hub) was created in Brisbane. Based in Sydney, the GI Hub seeks to improve the quality of public and private investments in infrastructure, further supporting the implementation of the G20 multi-year agenda (GI Hub, 2016); 05. the inclusion, for the first time in the agenda of the G20 
in Antalya, of the theme Digital economy/internet/IT, as a result of successive recommendations made by the $\mathrm{B} 20$ at previous summits.

Fourth, however, the question of protectionism may be perceived as an important point of dissensus between the B20 and G20. Although the B20's constant recommendations to combat protectionism and advance discussions within the WTO have always been met with some form of G20 commitment, in reality member countries have not yet agreed to implement substantive measures in this area - a situation made even more delicate after the election of Donald Trump to the US presidency and the policies adopted by his government with regard to international trade.

\section{Final considerations: The B20 and the process of (re)constructing hegemony}

The data and analysis presented here corroborates the hypothesis proposed about the existence of a 'B20 nucleus', comprised of business sectors present at most B20 summits, and to a large extent based in the North Atlantic countries. This inference is significant as it offers new empirical evidence that complements existing studies about the processes of formation and transformation of the transnational capitalist class, which relate to our two hypotheses. Ultimately, we can identify a convergence between the B20 and G20 (something that is even more explicit when we look at the 'B20 nucleus') around certain elements of the neoliberal model dominant prior to the 2008 crisis, while infusing it with some new and distinct elements - elements which, while not constitutive of the neoliberal model, are not necessarily antagonistic to it. That is to say, the incorporation of such 'new elements' does not necessarily mean questioning the structure of the current model, but rather points to areas that require some kind of action - such as the environment, the inclusion of women in the labor market, alternative energy sources and employability, for example. Furthermore, there are various points of consensus between the B20 and G20, although they involve distinct and sometimes even contradictory interests among B20 stakeholders. In many cases these point to the difficulty of maintaining hegemony and consensus within the globalist bloc, which may offer insights for future research on the limits of consensus in the context of crisis in the neoliberal model. 
Even so, despite these tensions inherent to the reproduction of hegemony in the context of crisis, over almost a decade the B20 has been consolidating itself as an important point of interaction between local and regional business elites and those of the North Atlantic - becoming an important point in the process of thinking about the impacts of the 'B20 nucleus'. As such, an important direction for future research concerns the relationship between this network and the rise of China: to what extent does this pose a threat to the constitutive hegemony of the globalist bloc in which B20 business sectors play a central role? To what extent will statist Chinese elites integrate into such a historic bloc, or will they end up causing fissures within it? (GRAAFF and APELDOORN, 2017). Questions of this kind raise questions that, while not the focus of the present article, require new reflections. Among these is the need for studies that map the network established between this particular manifestation of the transnational capitalist class, that is, the B20, and of its connections to the transnational capitalist class itself, identifying the most significant nodes of these interactions.

That is to say, looking at documents produced by the B20, identifying key agendas, themes and actors and establishing a brief comparison of these documents with those produced by the G20 during the same period, is extremely significant for understanding the role of social forces in the process of (re)constructing hegemonic relations on a transnational scale and between actors of different levels of analysis. Ultimately, although the present analysis is not based on a comprehensive adoption of a 'process tracing' methodology, its insights have been drawn upon to complement the document and content analysis proposed here. In this way, the present analyses are understood as important 'hoop tests' for arriving at a better understanding the dynamics of relations between social forces in this sphere. Ultimately, this means the identification of underlying causal mechanisms intimately connected to processes of (re)building global hegemony in a context of organic crisis.

Revised by Matthew Richmond Submitted on October 06, 2018 Accepted on April 15, 2019 


\section{References}

APELDOORN, Bastiaan van and GRAAFF, Naná de (2014). Corporate elites networks and US post-Cold War grand strategy from Clinton to Obama. European Journal of International Relations. Vol. 20, № 01, pp. 29-55.

BURT, Ronald S. (2004), Structural holes and good ideas. American Journal of Sociology. Vol. 110, № 02, pp. 349-399.

B20 (2017), B20 Policy recommendations to the G20. Available at <https://www.b20germany.org/fileadmin/user upload/documents/B20/b20summary-doc-en.pdf >. Accessed on July, 11, 2017.

B20 (2016), B20 2016 Policy recommendations to The G20. Available at $<$ http://en.b20-china.org/documents/report;sessionid=68C417CEFA80F511DF7C6742F5543B78 >. Accessed on February, 20, 2017.

B20 (2015a), B20 Policy achievements: assessment of alignment with the Antalya G20 leaders' communique. Available at $<$ http://b20turkey.org/policy-papers/ $>$. Accessed on June, 03, 2016.

B20 (2015b), B20 Policy proposals for the G20. Available at <http://b20turkey.org/policy-papers/>. Accessed on June, 03, 2016.

B20 (2015c), B20 Recommendations development process. Available at $<$ http://b20turkey.org/policy-papers/>. Accessed on June, 03, 2016.

B20 (2014), Driving growth and jobs: B20 Policy recommendations to the G20. Available at <http://www.g20.utoronto.ca/b20/index.html >. Accessed on June, 03, 2016.

B20 (2013), B20-G20 Partnership for growth and jobs: recommendations from Business 20. Available at <http://www.g20.utoronto.ca/b20/index.html $>$. Accessed on June, 03, 2016.

B20 (2012), Task force recommendations. Available at <http://www.g20.utoronto.ca/b20/index.html>. Accessed on June, 03, 2016.

B20 (2011), Final report: with appendices. Available at $<$ http://www.b20businesssummit.com/news/29-b20-final-report>. Accessed on June, 03, 2016.

B20 (2010a), Preliminary findings and recommendations from participants: discussion report for round table sessions. Available at $<$ www.g8.utoronto.ca/g20/b20/B20-2010-seoul-recs.pdf $>$. Accessed on June, 03, 2016. 
B20 (2010b), Seoul G20 Business Summit: joint statement by participating companies. Available at <http://www.g20.utoronto.ca/b20/B20-2010-seoulstatement.pdf $>$. Accessed on June, 03, 2016.

CAMMACK, Paul (2012), The G20, the crisis, and the rise of global developmental liberalism. Third World Quarterly. Vol. 33, № 01, pp. 01-16.

CARIN, Barry; HEINBECKER, Paul; SMITH, Gordon, and THAKUR, Ramesh (2010), Making the G20 Summit process work: some proposals for improving effectiveness and legitimacy. CIGI. Available at $<$ https://www.cigionline.org/sites/default/files/g20 no2 1.pdf>. Accessed on June, 03, 2016.

CARROLL, William K. (2010), The making of a transnational capitalist class: corporate power in the $21^{\text {st }}$ century. London: Zed Books. 320 pp..

CARROLL, Willian and CARSON, Colin (2003), The network of global corporations and elite policy groups: a structure for transnational capitalist class formation? Global Networks. Vol. 03, № 01, pp. 29-57.

COX, Robert W. (2002), The political economy of a plural world: critical reflections on power, morals and civilization. London: Routledge. 256 pp..

COX, Robert W. (1981), Social forces, states and world orders: beyond international relations theory. Millennium. Vol. 10, № 02, pp. 126-155.

DERVIŞ, Kemal and DRYSDALE, Peter (eds) (2014), The G-20 summit at five: time for strategic leadership. Washington: Brookings Institute Press. 302 pp..

FENNEMA, Meindert (1982), International networks of banks and industry. The Hague: Martinus Nijhoff Publishers. 148 pp..

GEGAFRICA (2015), Explaining the G20. Available at <http://gegafrica.org/g20-andafrica-monitor/explaining-the-g20 >. Accessed on June, 03, 2016.

GRAAFF, Naná de APELDOORN, Bastiaan van (2017), US elite power and the rise of 'statist' Chinese elites in global markets. International Politics. Vol. 54, № 03. pp. 338-355.

GILL, Stephen (2003), Power and resistence in the new world order. New York: Palgrave Macmillan. 238 pp..

GILL, Stephen (1990), American hegemony and the trilateral commission. New York: Cambridge University Press. 320 pp.. 
G20 (2017), G20 leader's declaration: shapping an interconnected world. Available at <http://www.g20.utoronto.ca/2017/2017-G20-leaders-declaration.html>. Accessed on July, 11, 2017.

G20 (2016), G20 leaders' communiqué: Hangzhou Summit. Available at $<$ http://www.g20.utoronto.ca/2016/160905-communique.html $>$. Accessed on February, 20, 2017.

G20 (2015a), G20 leader's communiqué. Available at $<$ http://www.g20.utoronto.ca/2015/151116-communique.html $>$. Accessed on June, 03, 2016.

G20 (2015b), G20 Members. Available at <http://g20.org.tr/about-g20/g20members/>. Accessed on January, 03, 2016.

G20 (2015c), International organisations. Available at <http://g20.org.tr/aboutg20/g20-members/international-organisations/>. Accessed on June, 03, 2016.

G20 (2015d), The G20 and the world. Available at <http://g20.org.tr/aboutg20/g20-members/g20-world/>. Accessed on June, 03, 2016.

G20 (2014a), G20 leaders' communiqué. Available at $<$ http://www.g20.utoronto.ca/2014/2014-1116-communique.htmls. Accessed on June, 03, 2016.

G20 (2014b), Working with partners. Available at $<$ http://www.g20.utoronto.ca/2014/Policy\%20Note\%20-

\%20Working\%20with\%20partners.pdf>. Accessed on January, 13, 2016.

G20 (2013), G20 leaders' declaration. Available at <http://www.g20.utoronto.ca/2013/2013-0906-declaration.html>. Accessed on June, 03 and 13, 2016.

G20 (2012), G20 Leaders' declaration. Available at $<$ http://www.g20.utoronto.ca/2012/2012-0619-loscabos.html>. Accessed on June, 03 and 11, 2016.

G20 (2011), Cannes Summit final declaration - Building our common future: renewed collective action for the benefit of all. Available at <http://www.g20.utoronto.ca/2011/2011-cannes-declaration-111104-en.html>. Accessed on June, 03, 2016.

G20 (2010), The G-20 Seoul Summit leader's declaration. Available at $<$ http://www.g20.utoronto.ca/2010/g20seoul.html>. Accessed on January, 13, 2016.

HAJNAL, Peter I. (2015), G7/8 and G20 accountability and civil society. In: The G8G20 relationship in global governance. Edited by LARIONOVA, Marina V. and KIRTON, John J.. London: Ashgate. pp. 173-197. 
HARRIS, Jerry R. (2014), Transnational capitalism and class formation. Science and Society. Vol. 78, № 03, pp. 312-333.

HARVEY, David (2005), A brief history of neoliberalism. Oxford: Oxford University Press. 256 pp..

HEEMSKERK, Eelke M.; FENNEMA, Meindert, and CARROL, William K. (2015), The global corporate elite after the financial crisis: evidence from the transnational network of interlocking directorates. Global Networks. Vol. 16, № 01, pp. 68-88.

HEEMSKERK, Eelke and TAKES, Frank (2015), The corporate elite community structure of global capitalism. New Political Economy. Vol. 21, № 01, pp. 90-118.

HELLEINER, Eric (2014), The status quo crisis: global financial governance after the 2008 financial Meltdown. Oxford University Press. 256 pp..

ICC (2015), Chairman meets with Chinese Vice Premier Wang Yang to strengthen business ties in China. Available at $<$ http://www.iccwbo.org/News/Articles/2015/ICC-Chairman-meets-withChinese-Vice-Premier-Wang-Yang-to-strengthen-business-ties-in-China/>. Accessed on November, 26, 2015.

KIELY, Ray (2015), The BRICs, US 'decline' and global transformations. Basingstoke: Palgrave McMillan. 243 pp..

LARIONOVA, Marina V.; RAKHMANGULOV, Mark; SAKHAROV, Andrei, and SHELEPOV, Andrey (2015), B20-G20 engagement: achievements and challenges. In: The G8-G20 relationship in global governance. Edited by LARIONOVA, Marina V. and KIRTON, John J.. London: Ashgate. pp. 143-182.

LUCKHURST Jonathan (2016), G20 since the global crisis. Basingstoke: Palgrave MacMillan. 300 pp..

MORTON, Adam David (2007), Unravelling Gramsci: hegemony and passive revolution in the global political economy. London: Pluto Press. 272 pp..

PIJL, Kees van der (2017), The BRICS - an involuntary contender bloc under attack. Estudos Internacionais. Vol. 05, № 01, pp. 25-46.

PIJL, Kees van der (1998), Transnational classes and international relations. London: Routledge. 213 pp..

RAMOS, Leonardo César Souza (2013), Hegemonia, revolução passiva e globalização: o sistema G7/8. Belo Horizonte: PUC Minas. 384 pp..

ROBINSON, William I. (2017), Debate on the new global capitalism: transnational capitalist class, transnational state apparatuses, and global crisis. International Critical Thought. Vol. 07, № 02, pp. 171-189. 
ROBINSON, William I. (2015), The transnational state and the BRICS: a global capitalism perspective. Third World Quarterly. Vol. 36, № 01, pp. 01-21.

ROBINSON, William I. (2010), Global capitalism theory and the emergence of transnational elites. WIDER Working Paper 2010/002. Helsinki: UNU-WIDER.

ROBINSON, William I. (2007), Beyond the theory of imperialism: global capitalism and the transnational state. Society Without Borders. Vol. 02, № 01, pp. 05-26.

ROBINSON, William I. (2005a), Global capitalism: the new transnationalism and the folly of conventional thinking. Science and Society. Vol. 60, № 03, pp. 316-328.

ROBINSON, William I. (2005b), Gramsci and globalisation: from nation-State to transnational hegemony. Critical Review of International Social and Political Philosophy. Vol. 08, № 04, pp. 559-574.

ROBINSON, William I. (2004), A theory of global capitalism: production, class, and State in a transnational world. Baltimore: Johns Hopkins University Press. XVI, $200 \mathrm{pp}$.

ROBINSON, William I. and HARRIS, Jerry (2000), Toward a global ruling class? Globalization and the transnational class. Available at <http://www.net4dem.org/mayglobal/Papers/RobinsonHarris7 16.pdfs. Accessed on April, 10, 2018.

SKLAIR, Leslie (2002), The transnational capitalist class and global politics: desconstructing the corporate-state connection. International Political Science Review. Vol. 23, № 02, pp. 159-174.

SKLAIR, Leslie (2001), The transnational capitalist class. Oxford: Blackwell. 352 pp..

SKLAIR, Leslie (2000), The transnational capitalist class and the discourse of globalization. Cambridge Review of International Affairs. Vol. 14, № 01, pp. 6785.

STAPLES, Cliford (2006), Board interlocks and the study of the transnational capitalist class. Journal of World-System Research. Vol. 12, № 02, pp. 309-319.

STREECK, Wolfgang (2016), How will capitalism end? Essays on a failing system. London: Verso. 272 pp..

VIANA, André Rego and CINTRA, Marcos Antonio Macedo (2010), G20: os desafios da coordenação global e da rerregulação financeira. In: IPEA - Boletim de Economia e Política Internacional, № 01. Edited by VIANA, André Rego. Brasília: IPEA. pp. 15-20.

WADE, Robert H. (2011), Emerging world order? From multipolarity to multilateralism in the G20, the World Bank, and the IMF. Politics \& Society. Vol. 39, № 03, pp. 347-378. 